CrossMark

\&lick for updates

Cite this: Food Funct., 2015, 6, 3437

\title{
Chitooligosaccharides as novel ingredients of fermented foods
}

\author{
M. S. Vela Gurovic, ${ }^{\star} \dagger^{a}$ M. Dello Staffolo, ${ }^{b}$ M. Montero, ${ }^{a}$ A. Debbaudt, ${ }^{a}$ L. Albertengo ${ }^{a}$ \\ and M. S. Rodríguez ${ }^{a}$
}

Chitooligosaccharides (COSs) have been clinically evaluated for their immunostimulating effects after oral intake. Similar to dietary supplements, prebiotics and biopreservatives, these water-soluble bioactives are easily incorporated into dairy products and beverages. Notwithstanding, the use of COS in fermented foods would be limited by its antimicrobial properties. In order to study the interaction with yoghurts as a model of fermented food, the effects of COS on chemical composition, viability, morphology and metabolism of lactic acid bacteria, fatty acid profiles and conjugated linoleic acid (CLA) were assessed over 28 days and after chemical digestion. There were no significant differences between the nutritional composition of controls and yoghurts supplemented with concentrations up to $0.1 \% \mathrm{w} / \mathrm{w}$ of COS. However, the acidification of milk decreased at $0.5 \%(p<0.05)$ and the formation of yoghurt failed at $3.0 \%$, without affecting viable counts. Lipid hydrolysis of yoghurts supplemented with $0.1 \%$ COS was not affected by chemical digestion. No significant differences were found between CLA percentages of controls and supplemented yoghurts after digestion. Although the nutritional composition, fatty acids and viable counts were not significantly modified after COS supplementation, the present study shows that COS diminishes bacterial acidification at concentrations higher than $0.1 \%$, thus limiting the amounts that could be added to yoghurt.

Received 14th May 2015,

Accepted 7th August 2015

DOI: $10.1039 /$ c5fo00546a

www.rsc.org/foodfunction a molecular weight of $3.8 \mathrm{kDa}$ or lower (DD $88 \%$ ) would display the best biological profiles.

Although commercial products based on COS have not been revised by the international regulatory organizations, some products containing the chitosan polymer have been recognized as safe dietary supplements or novel food ingredients by the FDA and EFSA. ${ }^{5-7}$ The chitosan GRAS (Generally Recognized As Safe) notice related to KiOfine ${ }^{\circledR}-\mathrm{B}$, a chitosan secondary food ingredient for food processing, ${ }^{8}$ claims that chitosan oligomers ( $<1 \mathrm{kDa}, \mathrm{DD} 70-95 \%)$ are non-toxic for humans and animals, even when consumed at high dietary concentrations. A clinical trial on the efficacy of orally administered chitooligosaccharides (FACOS ${ }^{\mathrm{TM}}, 3.5 \mathrm{kDa}$ ) on the immune function of healthy adults was completed in $2007 .{ }^{9}$ Although no results have been provided by the sponsor, this product has been subjected to clinical trials to test the effects on the immune function of healthy adults ${ }^{10}$ and the elderly. ${ }^{11}$ A daily dose of $2.6 \mathrm{~g}$ and $5.1 \mathrm{~g}$ for each group respectively led to a favorable behavior of cytokine levels in the treated group, without adverse effects. Orally administered as a dietary supplement, COS with a DD of $90 \%$ and a MW below $1.0 \mathrm{kDa}$ reduced the cholesterol levels in healthy men at a dose of $1 \mathrm{~g}$ per day. ${ }^{12}$ Again, no adverse effects were reported.

Chitosan oligosaccharides have been proposed as potential prebiotics, since they could stimulate beneficial bacteria while 
inhibiting intestinal pathogens. ${ }^{13}$ Lee et al. ${ }^{14}$ showed that COS (DP 2-8, MW < $1.5 \mathrm{kDa}$, DD 99.9\%) stimulated the growth of Bifidobacterium and Lactobacillus probiotic strains at concentrations ranging from 0.1 to $0.5 \%$. Accordingly, Liang et al. ${ }^{15}$ informed that COS (DP 4-9, MW $<1.7 \mathrm{kDa}$, DD 60\%) stimulated the growth of $L$. paracasei and L. kefir at $0.1 \%$ and concluded that oligomers with higher MWs inhibited their growth. In contrast, Fernandes et al. ${ }^{16}$ could not demonstrate prebiotic effects on the probiotics Bifidobacterium animalis and L. acidophilus using oligosaccharides with similar characteristics (MW $1.7 \mathrm{kDa}, \mathrm{DD}$ 65\%). These results would suggest that COS effects on bacterial growth are strain specific. Indeed, previous studies showed that COSs (MW $<5 \mathrm{kDa}, \mathrm{MW}<3 \mathrm{kDa}$, DD $80-85 \%$ ) inhibit Gram negative bacteria more than Gram positive bacteria. ${ }^{17,18}$ This could be attributed to differences in the cell wall, since COS but not chitosan could penetrate the cell wall of Gram negative bacteria and exert intracellular damage. Regarding the inhibition of undesirable bacteria, Wang et $a .^{19}$ recently reported that COS had the potential to reduce intestinal pathogen adhesion. Šimůnek et al. showed that the oligomers ( $\mathrm{MW}<2 \mathrm{kDa}, \mathrm{MW}<3 \mathrm{kDa}, \mathrm{MW}<6 \mathrm{kDa}$, DD $88 \%$ ) inhibit non-pathogenic human colonic bacteria weakly, while the growth rate of Bifidobacteria of human origin is not affected. ${ }^{20,21}$

Due to their antimicrobial properties against foodborne pathogens, COSs have been proposed as food biopreservatives. Tsai et ll. $^{22}$ reported that COSs (DP 1-8) prevented milk spoilage by inhibiting the growth of undesirable microbial species from 0.24 to $0.48 \%$. In another study, COS (DP $<5$, DD 80-85\%) displayed MICs and MLCs between 0.1 and $0.5 \% \mathrm{w} / \mathrm{v}$ against Escherichia coli and Staphylococcus aureus in milk and apple juice. ${ }^{23}$ According to Barreteau et al., ${ }^{24}$ COSs showed better properties than chitosan polymers against food borne pathogens. These authors also suggested that the antimicrobial properties of COS may not permit its use in fermented foods. A profitable product should be active against pathogens and innocuous to beneficial microorganisms such as starters, probiotics and intestinal bacteria associated with health. Regarding microbial strains used in the manufacture of yoghurts, it has been shown that COS (MW $<1.5 \mathrm{kDa}, 85 \%)$ activity against yoghurt starters $L$. delbrueckii and $S$. thermophilus depends on the COS concentration and initial bacterial load. It is worth mentioning that these oligomers were more tolerable than those of higher molecular weights. ${ }^{25}$

In the present study, we evaluate for the first time the effects of COS on yoghurt as the selected model of fermented food. Traditionally, yoghurt is produced by incubating concentrated milk with $L$. delbrueckii subsp. bulgaricus and S. thermophilus. $^{26}$ According to the standards for fermented milk, ${ }^{27}$ yoghurt must possess a high number of viable bacteria. ${ }^{28-30}$ Among yoghurt lipids, conjugated linoleic acid (CLA) has many biological properties that contribute to its nutritional value. $^{29}$ It accumulates preferably in cheese and yoghurt in quantities ranging from 1 to $9 \mathrm{mg}$ per $\mathrm{g}$ of lipid. ${ }^{31}$ CLA comprises those isomers of linoleic acid possessing conjugated double bonds, a structural feature that confers chemical instability to the molecule and the ability to react against free radicals. $^{32}$

Bearing in mind the increasing interest in the use of COS as novel food ingredients, the present study aims to evaluate whether COS modifies the nutritional properties of yoghurt, such as nutritional composition, viable counts of lactic acid bacteria (LAB) and fatty acid profiles. In order to determine the effects of COS thoroughly, fatty acid profiles and viable counts were monitored over a storage period of 28 days. Additionally, a sensory acceptance study on yoghurts supplemented with COS was performed.

Taking into account that chitosan, a polycationic polymer, interferes with lipid absorption by binding lipids and fatty acids, ${ }^{33,34}$ the lipolysis, fatty acid profiles and CLA content were studied after chemical digestion of fresh yoghurts supplemented with COS.

\section{Materials and methods}

\section{Preparation of chitooligosaccharides}

Chitosan was obtained from shrimp (Pleoticus mülleri) waste as previously reported. ${ }^{35}$ The chitosan average molecular weight was $468186 \mathrm{kDa}$, assessed by viscometry and calculated from experimental intrinsic viscosity by utilizing the MarkHouwink-Kuhn-Sakurada equation. ${ }^{36}$ The moisture content was $6.58 \%$ and the ash content was $0.53 \%$. The degree of deacetylation (DD) was assessed by procedures described previously. ${ }^{37}$ Hydrolysis of chitosan (2 g) was performed with $12.5 \% \mathrm{v} / \mathrm{v} \mathrm{H}_{2} \mathrm{O}_{2}$ for $20 \mathrm{~min}$ at room temperature. After being irradiated in a microwave oven at $700 \mathrm{~W}$ for $4 \mathrm{~min}$, the sample was cooled at room temperature and filtered under reduced pressure. The chitooligosaccharides were precipitated with $150 \mathrm{~mL}$ of $98 \% \mathrm{v} / \mathrm{v}$ ethanol from the filtrate. After $15 \mathrm{~min}$, the residue was filtered under reduced pressure and washed several times with ethanol until a negative reaction with $\mathrm{KMnO}_{4}(0.02 \mathrm{M})$ confirmed the absence of $\mathrm{H}_{2} \mathrm{O}_{2}$. The resulting product was dissolved in distilled water and freeze dried. All reagents were of analytical grade. The COS average molecular weight was $2.764 \mathrm{kDa}$, moisture content was $13.3 \%$, ash content was $2.60 \%$ and DD was $68 \%$.

\section{Preparation of yoghurt}

Yoghurt was prepared according to a method previously reported. ${ }^{38}$ Reconstituted skim milk (15\% w/w, La Serenísima, Argentina) with $5 \%$ sucrose was heated to $80{ }^{\circ} \mathrm{C}$ for $30 \mathrm{~min}$, cooled to room temperature and supplemented with $0.05,0.1$, 0.5 and $3 \% \mathrm{w} / \mathrm{w}$ COS. After homogenization, $1 \mathrm{~mL}$ of a fresh culture of Streptococcus thermophilus (CP2 CIDCA collection 321 ) and $1 \mathrm{~mL}$ of Lactobacillus delbrueckii subsp. bulgaricus (Lbp, CIDCA collection 332) were added to $100 \mathrm{~g}$ of milk with sucrose and supplemented with COS. Controls were obtained by the same procedures without the addition of COS. Samples were incubated at $40 \pm 1{ }^{\circ} \mathrm{C}$ until pH 4.4-4.6 and stored at $4 \pm 1^{\circ} \mathrm{C}$ after completion of the fermentation process. The starters were activated for 24 to $48 \mathrm{~h}$ at $40 \pm 1^{\circ} \mathrm{C}$ in autoclaved skim 
milk ( $\left.120{ }^{\circ} \mathrm{C}, 20 \mathrm{~min}\right)$ before inoculating the yoghurts, until a biomass of $\sim 10^{8} \mathrm{CFU}$ per $\mathrm{mL}$ was reached. All analyses were performed in triplicates.

\section{Viable counts}

Aliquots of $1 \mathrm{~g}$ of yoghurt were suspended in $100 \mathrm{~mL}$ of sterile physiological solution. Serial dilutions were prepared and 100 $\mu \mathrm{L}$ of each dilution was spread over De Man, Rogosa and Sharpe agar plates (Laboratorios Britania S.R.L., Buenos Aires, Argentina). The plates were incubated for $24 \mathrm{~h}$ at $40 \pm 1{ }^{\circ} \mathrm{C}$. Colonies growing under these conditions were counted and identified as lactic acid bacteria. Samples were analyzed in triplicates.

\section{Microscopy}

Gram staining was performed in order to check for general morphology and contamination. Aliquots of $5 \mu \mathrm{L}$ yoghurt samples diluted in $1 / 10 \mathrm{v} / \mathrm{v}$ of sterile physiological solution $(0.85 \% \mathrm{NaCl}$, analytical grade) were fixed on glass slides and stained according to the instructions of the kit supplier (Gram Britania, Argentina). The samples were observed under an optical microscope. The morphology of lactobacilli and streptococci of controls and yoghurt samples treated with COS was observed with a Scanning Electron Microscope LEO EVO 40 (Zeiss, Germany). Cells were adhered using polylysine surfaces by a method reported previously. ${ }^{39,40}$

\section{Compositional analyses}

Yoghurt samples were analyzed after $24 \mathrm{~h}$ storage at $4^{\circ} \mathrm{C}$. The protein content was measured by the Kjeldahl method using the conversion factor 6.38 (method $24.027, \mathrm{AOAC}),{ }^{41}$ and the fat content was determined by the Gerber method. Acidity was measured by titration with $0.1 \mathrm{~N} \mathrm{NaOH}$, and expressed as the percentage of lactic acid ( $\mathrm{g}$ lactic acid per $100 \mathrm{~g}$, method 907.124, AOAC). ${ }^{42}$ The ash content was quantified by dry ashing the samples in a muffle furnace at $550^{\circ} \mathrm{C}$ for $24 \mathrm{~h}$ (method 24.009, AOAC). ${ }^{41}$ The water content was determined by oven drying at $105{ }^{\circ} \mathrm{C}$ (method 24.002, AOAC). ${ }^{41}$ All analyses were performed in triplicates. All reagents were of analytical grade.

\section{Lipid extraction and fatty acid methylation}

Aliquots of $700 \mathrm{mg}$ of yoghurt were extracted three times with $700 \mu \mathrm{L}$ of a chloroform/methanol solution (2:1 v/v, analytical grade, Cicarelli, $\geq 99.0 \%$, Buenos Aires, Argentina). In order to improve the extraction, samples were shaken at $230 \mathrm{rpm}$ for $15 \mathrm{~min}$. To disrupt the emulsion, samples were centrifuged at $4200 \mathrm{rpm}$ for $5 \mathrm{~min}$. The organic phase was collected and poured into a clean glass tube. Samples were reduced under a nitrogen stream, and $1 \mathrm{~mL}$ of $10 \%$ methanolic $\mathrm{HCl}(\mathrm{v} / \mathrm{v})$ was added. This solution was prepared with $37 \% \mathrm{HCl}(\mathrm{w} / \mathrm{v})$ (for analysis, Merck, Buenos Aires, Argentina) and anhydrous methanol (analytical grade, Biopack, $\geq 99.8 \%$, Buenos Aires, Argentina). The reaction was held at $50{ }^{\circ} \mathrm{C}$ for $20 \mathrm{~min}$. After cooling the samples to room temperature, fatty acid methyl esters were extracted twice with $1 \mathrm{~mL}$ of $n$-hexane (chromatographic grade, U.V.E. Dorwil, Buenos Aires, Argentina) and washed once with $1 \mathrm{~mL}$ of $1.2 \% \mathrm{NaOH}(\mathrm{w} / \mathrm{v})$ (analytical grade, Anedra, $\geq 99.8 \%$, Buenos Aires, Argentina). Samples were immediately dried under a nitrogen stream and subjected to chromatographic analysis or stored under a nitrogen atmosphere. Lipids were extracted by similar procedures after chemical digestion. Aliquots of $15 \mathrm{~mL}$ of the digested suspension were extracted three times with the same volume of the chloroform/methanol solution $(2: 1, \mathrm{v} / \mathrm{v})$, mixed and centrifuged. The organic phase was concentrated with a rotatory evaporator at $45^{\circ} \mathrm{C}$ and the resulting extracts were dried under a nitrogen stream. Samples were dissolved in $500 \mu \mathrm{L}$ of deuterated chloroform for NMR analyses. Once the spectra were recorded, $100 \mu \mathrm{L}$ of the total volume was methylated for GC-MS analyses. All analyses were performed in triplicates.

\section{Gas chromatography analyses}

Fatty acid methyl esters were analyzed by GC-MS with a 7890B chromatograph equipped with a mass spectrometer 5977A (Agilent Technologies). The ionization mode was electron impact and the ionization energy was $70 \mathrm{eV}$. Samples $(1 \mu \mathrm{L})$ were injected into a HP-5Ms capillary column $(30 \mathrm{~m} \times$ $0.25 \mathrm{~mm}$ i.d. $\times 0.25 \mu \mathrm{m}$ film thickness). The temperature was programmed from $150{ }^{\circ} \mathrm{C}$ to $250{ }^{\circ} \mathrm{C}$ at a rate of $4^{\circ} \mathrm{C} \min ^{-1}$ and held at the final temperature for $15 \mathrm{~min}$. The injector and detector temperature was $280{ }^{\circ} \mathrm{C}$; the carrier gas was helium at a flow rate of $1 \mathrm{~mL} \mathrm{~min}^{-1}$ and the split ratio was $20: 1$. Fatty acid compositions were expressed as relative percentages (w/w). CLA isomers were identified by comparing their retention times and mass fragmentation patterns with those of the standards: c9,t11-octadecadienoic acid, t10,c12 and other minor isomers, including t9,t11. Standards of methyl esters of conjugated linoleic acid were purchased from Sigma-Aldrich Chemical Co., St Louis, MO, USA (CODE O5507).

\section{Nuclear magnetic resonance experiments}

${ }^{1} \mathrm{H}$ NMR spectra of lipid extracts were acquired with a Bruker Avance Ultrashield $300 \mathrm{MHz}$ NMR spectrometer using $\mathrm{CDCl}_{3}$ (99.8 atom\% D, Sigma-Aldrich Chemical Co., St Louis, MO, USA, CODE 151823) as the solvent and residual protons as the internal reference $(7.26 \mathrm{ppm})$. Spectra were recorded at $300 \mathrm{~K}$, 16 scans with a spectral width of $6000 \mathrm{~Hz}$.

\section{Digestive chemical experimental model}

The chemical digestion has been previously described by Rodríguez et al. ${ }^{35}$ Procedures were performed as follows: $12.5 \mathrm{~g}$ of yoghurt was stirred in $50 \mathrm{~mL}$ of $0.1 \mathrm{M} \mathrm{HCl}$ (Merck) for $1 \mathrm{~h}$ at $\mathrm{pH}$ 1.0-2.0, at $30 \mathrm{rpm}$ and $37^{\circ} \mathrm{C}$ to reproduce the gastric environment. The $\mathrm{pH}$ was adjusted to 6.8-7.2 with $15 \mathrm{~g}$ per $\mathrm{L}$ of $\mathrm{NaHCO}_{3}$ (Sigma Chemical Co., St Louis, MO, USA) and the stirring speed was increased from 30 to $300 \mathrm{rpm}$, while the temperature was maintained at $37^{\circ} \mathrm{C}$ to reproduce the duodenal environment. All reagents were of analytical grade.

\section{Sensory evaluation}

Sensory evaluation was done in the morning in a standardized test room, by an affective test with a 9-point structured scale 
( 1 for 'dislike extremely' and 9 for 'like extremely'). Yoghurt samples $(10 \mathrm{~g})$ with and without $0.1 \%$ COSs were served at $10{ }^{\circ} \mathrm{C}$ in white plastic cups coded with random three digit numbers. Mineral water was provided for mouth-rinsing. The attributes of overall acceptability, flavor, color and texture were evaluated by a panel of 30 non-trained judges to determine the acceptability of the yoghurts. ${ }^{43}$

\section{Statistical analyses}

Relative percentages of compositional analysis are expressed as the mean and standard error of the mean. Significant differences were tested using a two-way ANOVA. Post-tests were performed using the Bonferroni method for multiple comparisons.

\section{Results and discussion}

The composition of yoghurts obtained by fermentation of milk supplemented with 0.1 and $0.05 \% \mathrm{w} / \mathrm{w}$ of COS satisfied the standards for yoghurt as defined by the Codex Alimentarius. ${ }^{27}$

At a concentration of $0.5 \% \mathrm{w} / \mathrm{w}$, the lactic acid percentage decreased significantly $(p<0.05$, Table 1$)$ to reach the minimum accepted by the Codex. ${ }^{27}$ When COS was added to
$3.0 \% \mathrm{w} / \mathrm{w}$, the acidification failed in such a way that protein coagulation did not occur and the product consistency resembled that of milk (data not shown). This suggests that lactic acid production, and thus bacterial metabolic activity, was markedly affected by increasing concentrations of COS when it exceeded $0.5 \% \mathrm{w} / \mathrm{w}$. The viable counts of LAB, however, remained in the order of $10^{8} \mathrm{CFU}$ per $\mathrm{g}$ at $0,0.05,0.1$ and $0.5 \% \mathrm{w} / \mathrm{w}$ COS. The water content decreased when COS was added. This suggests that COS, like other oligosaccharides, is able to retain water. Other nutritional characteristics of yoghurts such as the fat and protein content were not altered.

Minor changes in bacterial morphology were recorded. Bacteria growing in yoghurts supplemented with $0.1 \%$ COS appeared to be larger. Cocci growing in control yoghurts showed an average diameter of $630 \mathrm{~nm}$, while the diameter of cocci growing in supplemented yoghurts $(0.1 \%)$ was $800 \mathrm{~nm}$. For bacilli the diameters were $580 \mathrm{~nm}$ and $770 \mathrm{~nm}$, respectively. The effect of $0.1 \%$ COSs on the cell size could be related to their harmful effects on the cell wall, ${ }^{18}$ since its integrity is necessary for the maintenance of cell shape. ${ }^{44}$

Besides, a reduction in the number of cells per field in yoghurt supplemented with $0.5 \%$ COS was clearly noticed when compared with the other groups (Fig. 1, 4000×). Prob-

Table 1 Composition of yoghurts supplemented with $\mathrm{COS}^{a}$

\begin{tabular}{|c|c|c|c|c|c|c|}
\hline & Acidity (\% lactic acid) & Fat $(g \%)$ & Water content (g\%) & Protein $(g \%)$ & $\operatorname{Ash}(\mathrm{g} \%)$ & CFU per $g(24 \mathrm{~h})$ \\
\hline Control & $1.57 \pm 0.02$ & $1.45 \pm 0.05$ & $83.70 \pm 1.45$ & $3.10 \pm 0.15$ & $0.86 \pm 0.01$ & $8.310^{8} \pm 0.04$ \\
\hline $0.05 \%$ & $1.60 \pm 0.02$ & $1.50 \pm 0.01$ & $80.80 \pm 0.01^{b}$ & $3.00 \pm 0.15$ & $0.87 \pm 0.01$ & $8.410^{8} \pm 0.09$ \\
\hline $0.1 \%$ & $1.49 \pm 0.05$ & $1.55 \pm 0.05$ & $80.85 \pm 0.15^{b}$ & $2.97 \pm 0.17$ & $0.85 \pm 0.01$ & $8.310^{8} \pm 0.10$ \\
\hline $0.5 \%$ & $0.68 \pm 0.01^{b}$ & $1.55 \pm 0.05$ & $79.50 \pm 0.50^{c}$ & $3.40 \pm 0.10$ & $0.87 \pm 0.01$ & $2.210^{8} \pm 0.10$ \\
\hline
\end{tabular}

${ }^{a}$ Mean values \pm S.E.M. ${ }^{b} p<0.05$ compared with control. ${ }^{c} p<0.001$ compared with control.
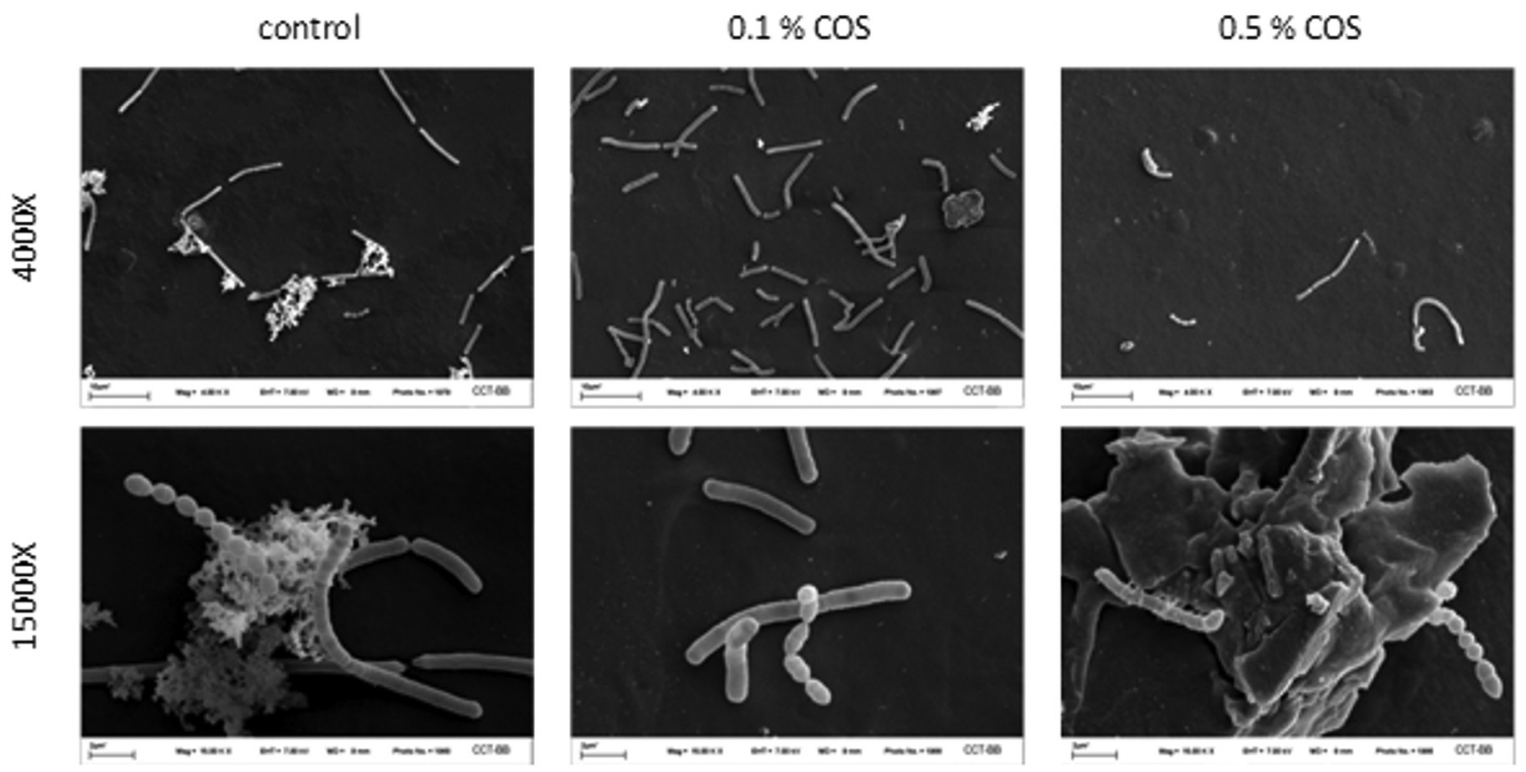

Fig. 1 SEM micrographs of yoghurts supplemented with COS. 
ably, lactobacilli and streptococci grown in the presence of $0.5 \%$ COS were less resistant to the treatment with polylysine used to fix cells for scanning electron microcopy. At this concentration, a significant decrease in lactic acid production also evidenced a clear inhibition on bacterial metabolic activity (Table 1).

Fernandes et $a .^{16}$ found that COS $(1.7 \mathrm{kDa}$, DD 65\%) affected the growth of probiotic bacteria, although cell dimensions were not affected. In accordance with previous studies on different species, ${ }^{18}$ they suggested the prevention of nutrient uptake as a mechanism of growth inhibition. Other COS effects regarding the water content were observed in the present study. This could also play a role in the mechanisms that cause bacterial metabolic changes. Considering these preliminary results, concentrations of $0.1 \%$ and $0.05 \%$ were selected for further analyses.

Titratable acidity and viable counts were monitored for a storage period of 28 days at $4{ }^{\circ} \mathrm{C}$ (Fig. 2). The acidity tended to increase from day 1 to day 21 , and decrease at day 28 . However, these variations were not statistically significant, except for titratable acidity between control and $0.1 \%$ COS yoghurts at day $1(p<0.05)$. For viable counts the contrary ten-

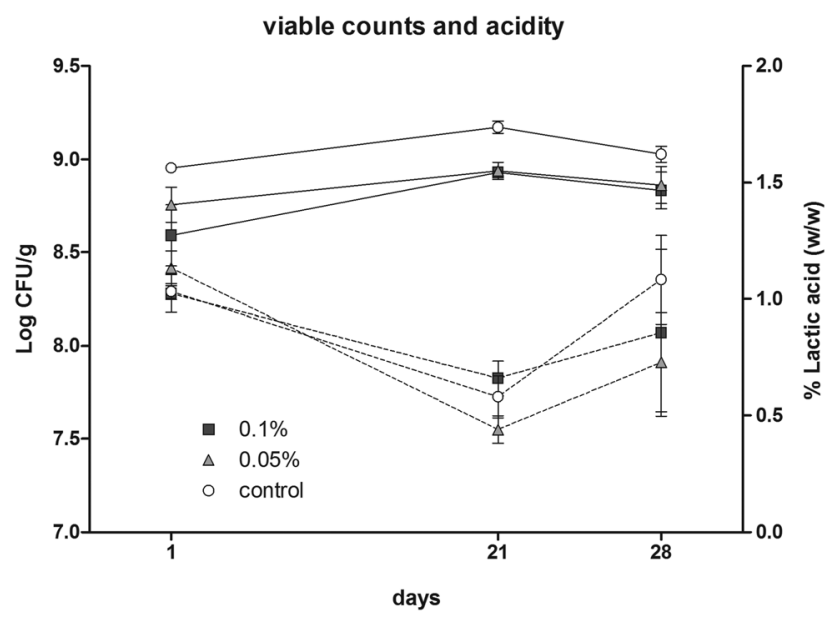

Fig. 2 Titratable acidity (solid line) and viable counts (dashed line) of yoghurts at days 1,21 and 28 of storage. dency was observed. Viable counts remained above $10^{7} \mathrm{CFU}$ per $\mathrm{g}$ over the period and acidity was in the range of $1.2-1.8 \mathrm{~g}$ lactic acid per $100 \mathrm{~g}$. These results were in accordance with the standards defined for yoghurts. ${ }^{27}$

A chemical gastrointestinal digestion of yoghurts supplemented with $0.1 \%$ COS was simulated by an in vitro model. Lipids were extracted from the resulting suspension and analyzed by ${ }^{1} \mathrm{H}$ NMR. Lipolysis was evidenced by different patterns of the ${ }^{1} \mathrm{H}$ NMR signals between 3.5 and $4.5 \mathrm{ppm}$ assigned to glyceryl protons (signals Gly2 on Fig. 3). Before digestion, these signals appeared as a system of two double doublets at 4.29 and $4.15 \mathrm{ppm}$. The chemical shift and multiplicity of these signals are notably affected by the presence or absence of the acyl chains attached to the glyceryl backbone. ${ }^{45}$ Monoand di-glycerides were evidenced by new signals appearing between $4.17 \mathrm{ppm}$ and $3.60 \mathrm{ppm}$. Both digested samples, namely the control and supplemented yoghurts showed almost identical lipolytic and fatty acid profiles (Fig. 3 and Table 3, respectively).

As shown in Table 3, no significant differences were found between the CLA percentages of the control and supplemented yoghurts.

However, when the fatty acid profiles of Table 3 were compared with data shown in Table 2, it was clear that CLA percentages were reduced after chemical digestion in yoghurts supplemented with COS. During storage, these percentages ranged from 0.6 to $1.2 \%$ in the supplemented groups, but decreased to $0.1 \%$ after digestion. The CLA percentages of fresh yoghurts supplemented with $\operatorname{COS} 0.1 \%$ (day 1) were significantly different from the CLA percentages after digestion $(p<0.001, t$-test). In contrast, the CLA percentages of controls were not different before and after digestion. This shows that labile substances such as CLA are affected by the presence of $\mathrm{COS}$ in chemical environments that mimic gastrointestinal processes.

The application of a sensory methodology affords early results for the food product development, providing prior knowledge with respect to its acceptance in the consumer market and/or specific characteristics. In this study, yoghurt with $0.1 \% \mathrm{w} / \mathrm{w}$ COS was selected for the affective test since it was the maximum concentration that showed suitable results in the performed assays. Good acceptance was obtained by
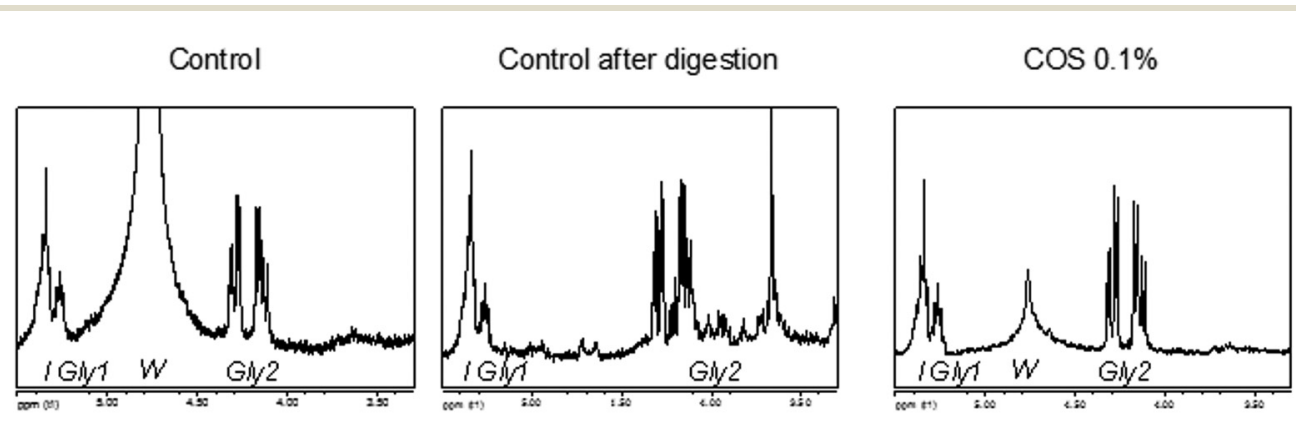

$\cos 0.1 \%$ after digestion

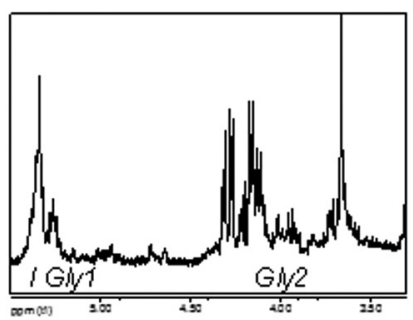

Fig. 3 Sections of ${ }^{1} \mathrm{H}$ NMR spectra of yoghurt lipids. Gly1 and Gly2 refer to glyceryl protons attached to $\mathrm{C} 2$ and $\mathrm{C} 1 / \mathrm{C} 3$ respectively. I = olefinic protons. $\mathrm{W}=$ water signal. 
Table 2 Fatty acid profiles of yoghurts supplemented with COS over 28 days of storage

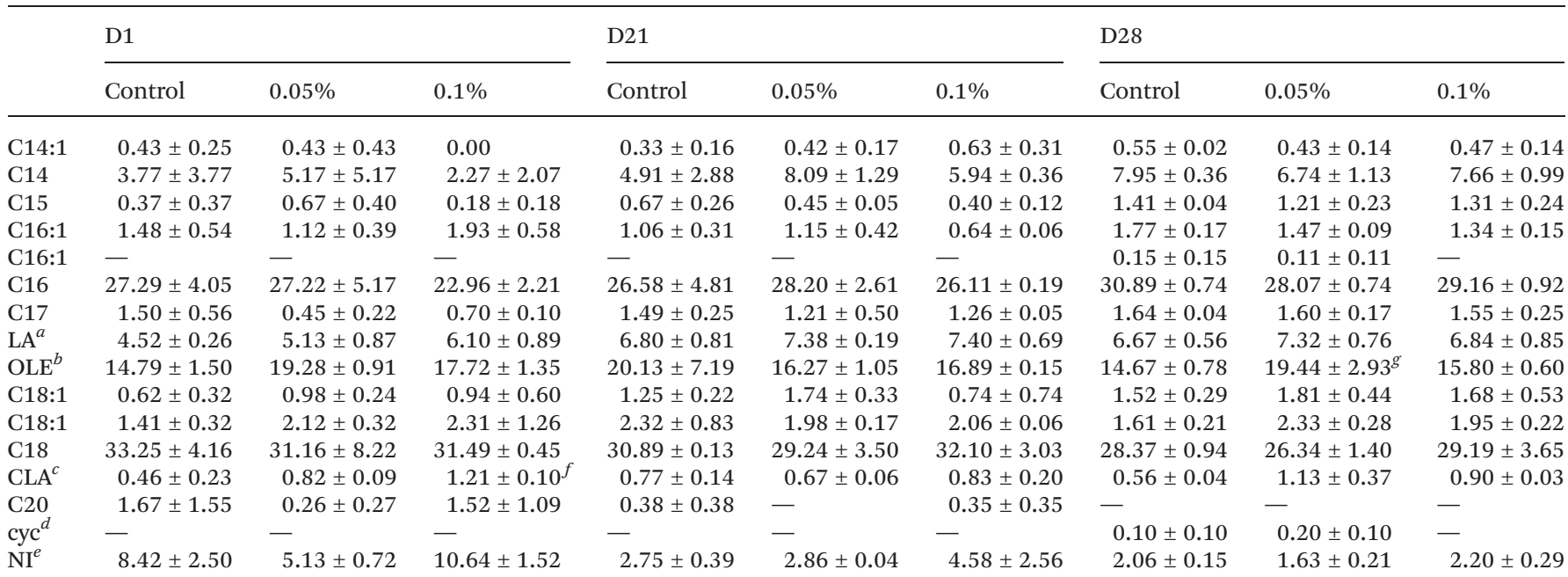

${ }^{a}$ Linoleic acid. ${ }^{b}$ Oleic acid. ${ }^{c}$ Conjugated linoleic acid. ${ }^{d}$ Lactobacillic acid. ${ }^{e}$ Not identified. ${ }^{f} p<0.05$ compared with control D1. ${ }^{g} p<0.001$ compared with control D28.

Table 3 Fatty acid profiles of chemically digested yoghurts

\begin{tabular}{lcc}
\hline & \multicolumn{1}{c}{ Control } & $0.1 \%$ COS \\
\hline C14:1 & $0.54 \pm 0.04$ & $0.18 \pm 0.18$ \\
C14 & $7.27 \pm 0.04$ & $3.36 \pm 1.47$ \\
C15 & $1.27 \pm 0.06$ & $0.43 \pm 0.43$ \\
C16:1 & $2.54 \pm 0.43$ & $1.54 \pm 1.54$ \\
C16:1 & $0.58 \pm 0.14$ & $0.40 \pm 0.40$ \\
C16 & $33.85 \pm 1.49$ & $30.03 \pm 1.53$ \\
C17 & $1.38 \pm 0.74$ & $0.23 \pm 0.23$ \\
LA $^{a}$ & $7.33 \pm 1.77$ & $8.98 \pm 3.51$ \\
OLE $^{b}$ & $13.68 \pm 0.52$ & $13.88 \pm 2.19$ \\
C18:1 & $2.29 \pm 0.19$ & $1.46 \pm 0.31$ \\
C18:1 & $1.05 \pm 0.15$ & $0.54 \pm 0.54$ \\
C18 & $25.23 \pm 5.0$ & $33.59 \pm 12.04$ \\
CLA & $0.42 \pm 0.07$ & $0.17 \pm 0.02$ \\
NI $^{c}$ & $2.86 \pm 0.89$ & $5.77 \pm 0.88$
\end{tabular}

${ }^{a}$ Linoleic acid. ${ }^{b}$ Oleic acid. ${ }^{c}$ Not identified.

yoghurts with $0.1 \% \mathrm{w} / \mathrm{w}$ COS, getting scores of 6 to 7 (data not shown). Moreover, no differences between the control and supplemented yoghurts on the attributes studied (overall acceptability, flavor, color and texture) were found in the statistical analysis.

\section{Conclusions}

The nutritional and organoleptic properties of yoghurts were not modified at $0.1 \% \mathrm{w} / \mathrm{w}$ or lower concentrations of COS. Higher concentrations caused metabolic alterations in lactic acid bacteria, evidenced by a decrease in lactic acid production. Consequently, the product obtained did not fulfill the standards defined for yoghurt by the Codex Alimentarius. ${ }^{27}$ Taking this into account, chitooligosaccharides (MW 2.7 kDa,
DD $68 \%$ ) could be incorporated into yoghurts at a maximum concentration of $0.1 \% \mathrm{w} / \mathrm{w}$ with good sensory acceptance. Since the doses required for clinical trials range from $1 \%$ to $5 \%$ per day, it would not be possible to incorporate such quantities into yoghurts without affecting the microbial fermentation process. If a health promoter effect is pursued, the desired amount of COS should be added to yoghurt immediately before consumption. Regarding prebiotics and biopreservatives, doses up to $0.1 \%$ COS could be used without causing metabolic inhibition of starters. Bearing in mind the increasing interest on COS benefits for human health and the food industry, the outcomes of the present study will certainly contribute to a better use of these oligosaccharides as food ingredients.

\section{Acknowledgements}

Financial support from Universidad Nacional del Sur (PGI-UNS No. 24/Q057), UNLP (Proy.X714) and CONICET (PIP0480). Dr M. S. Vela Gurovic acknowledges CONICET for a postdoctoral grant.

\section{References}

1 Y.-J. Jeon, F. Shahidi and S.-K. Kim, Food Rev. Int., 2000, 16, 159-176.

2 B. B. Aam, E. B. Heggset, A. L. Norberg, M. Sørlie, K. M. Vårum and V. G. H. Eijsink, Mar. Drugs, 2010, 8, 1482-1517.

3 R. K. Baboota, M. Bishnoi, P. Ambalam, K. K. Kondepudi, S. M. Sarma, R. K. Boparai and K. Podili, J. Funct. Foods, 2013, 5, 997-1012. 
4 S. Y. Chae, M.-K. Jang and J.-W. Nah, J. Controlled Release, 2005, 102, 383-394.

5 M. Hayes, in Marine Bioactive Compounds, ed. M. Hayes, Springer, US, 2012, ch. 4, pp. 115-128.

6 European Food Safety Authority, Panel on Dietetic Products, Nutrition and Allergies (NDA), Scientific Opinion, EFSA J., 2010, 8, 1687.

7 European Food Safety Authority, Panel on Dietetic Products, Nutrition and Allergies (NDA), Scientific Opinion, EFSA J, 2011, 9, 2214.

8 Food and Drug Administration, GRAS notice GRN0003697, Kitozyme S. A., 2011.

9 National Institutes of Health, US, https://clinicaltrials.gov/ ct2/show/study/NCT00468962, (accessed May 2015).

10 H.-J. Hwang, J.-A. Im and S.-H. Kim, J. Chitin Chitosan, 2009, 14, 125-129.

11 H. M. Kim, S. H. Hong, S. J. Yoo, K. S. Baek, Y. J. Jeon and S. Y. Choung, J. Med. Food, 2006, 9, 427-430.

12 C.-R. Choi, E.-K. Kim, Y.-S. Kim, J.-Y. Je, S.-H. An, J. D. Lee, J. Howang, S. S. Ki, B.-T. Jeon, S.-H. Moon and P.-J. Park, Int. J. Food Sci. Nutr., 2012, 63, 103-106.

13 M. Roberfroid, G. R. Gibson, L. Hoyles, A. L. McCartney, R. Rastall, I. Rowland, D. Wolvers, B. Watzl, H. Szajewska, B. Stahl, F. Guarner, F. Respondek, K. Whelan, V. Coxam, M.-J. Davicco, L. Léotoing, Y. Wittrant, N. M. Delzenne, P. D. Cani, A. M. Neyrinck and A. Meheust, Br. J. Nutr., 2010, 104, S1-S63.

14 H. W. Lee, Y. S. Park, J. S. Jung and W. S. Shin, Anaerobe, 2002, 8, 319-324.

15 T. W. Liang, C. P. Liu, C. Wu and S. L. Wang, Carbohydr. Polym., 2013, 92, 2141-2148.

16 J. C. Fernandes, P. Eaton, I. Franco, O. S. Ramos, S. Sousa, H. Nascimento, A. Gomes, A. Santos-Silva, F. X. Malcata and M. E. Pintado, Int. J. Biol. Macromol., 2012, 50, 148152.

17 J. C. Fernandes, K. F. Tavaria, S. C. Fonseca, Ó. S. Ramos, M. E. Pintado and F. X. Malcata, J. Microbiol. Biotechnol., 2010, 20, 311-318.

18 P. Eaton, J. C. Fernandes, E. Pereira, M. E. Pintado and F. X. Malcata, Ultramicroscopy, 2008, 108, 1128-1134.

19 S. Wang, J. Wang, H. Mou, B. Luo and X. Jiang, Foodborne Pathog. Dis., 2015, 12, 360-365.

20 J. Šimůnek, I. Koppová, L. Filip, G. Tishchenko and G. Bełżecki, Folia Microbiol., 2010, 55, 379-382.

21 J. Šimůnek, V. Brandysová, I. Koppová and J. Šimůnek Jr., Folia Microbiol., 2012, 57, 341-345.

22 G. J. Tsai, Z. Y. Wu and W. H. Su, J. Food Prot., 2000, 63, 747-752.
23 J. C. Fernandes, F. K. Tavaria, J. C. Soares, O. S. Ramos, M. J. Monteiro, M. E. Pintado and F. X. Malcata, Food Microbiol., 2008, 25, 922-928.

24 H. Barreteau, C. Delattre and P. Michaud, Food Technol. Biotechnol., 2006, 44, 323-333.

25 S. F. Ausar, N. Passalacqua, L. F. Castagna, I. D. Bianco and D. M. Beltramo, Int. Dairy J., 2002, 12, 899-906.

26 A. Y. Tamime, Eur. J. Clin. Nutr., 2002, 56, S2-S15.

27 Codex Standard for Fermented Milks, CODEX STAN 2432003.

28 D. A. Savaiano, Am. J. Clin. Nutr., 2014, 99, 1251S-1255S.

29 O. Adolfsson, S. N. Meydani and R. M. Russell, Am. J. Clin. Nutr., 2004, 80, 245-256.

30 F. Guarner, G. Perdigon, G. Corthier, S. Salminen, B. Koletzko and L. Morelli, Br. J. Nutr., 2005, 93, 783-786.

31 J. Csapó and É. Varga-Visi, in Advances in Fermented Foods and Beverages, ed. W. Holzapfel, Woodhead Publishing, United Kingdom, 2014, ch. 4, pp. 75-105.

32 N. Fagali and A. Catalá, Biophys. Chem., 2008, 137, 56-62.

33 J. L. Nauss, J. L. Thompson and J. Nagyvary, Lipids, 1983, 18, 714-719.

34 M. Beysseriat, E. A. Decker and D. J. McClements, Food Hydrocolloids, 2006, 20, 800-809.

35 M. S. Rodríguez, M. Montero, M. DelloStaffolo, M. Martino, A. Bevilacqua and L. Albertengo, Carbohydr. Polym., 2008, 74, 797-801.

36 G. A. F. Roberts and J. G. Domszy, Int. J. Biol. Macromol., 1982, 4, 374-377.

37 M. C. Terrile, A. Y. Mansilla, L. Albertengo, M. S. Rodríguez and C. A. Casalongué, Pest Manage. Sci., 2015, 71, 668-674.

38 M. DelloStaffolo, N. Bértola, M. Martino and A. Bevilacqua, Int. Dairy J., 2004, 14, 263-268.

39 M. Postek, K. Howard, A. Jhonson and K. McMichael, in Scanning Electron Microscopy a student's handbook, Ladd Research Industries, Burlington, USA, 1980.

40 D. Mazia, G. Schatten and W. Sale, J. Cell Biol., 1975, 66, 198-200.

41 Association of Official Analytical Chemists, Official methods of analysis, Washington, USA, 14th edn, 1984.

42 Association of Official Analytical Chemists, Official methods of analysis, Arlington, USA, 13rd edn, 1995.

43 M. O. Ramírez-Sucre and J. F. Vélez-Ruiz, LWT - Food Sci. Technol., 2013, 51, 233-241.

44 G. Misra, E. R. Rojas, A. Gopinathan and K. C. Huang, Biophys. J., 2013, 104, 2342-2352.

45 B. Nieva-Echevarría, E. Goicoechea, M. J. Manzanos and M. D. Guillén, Food Res. Int., 2014, 66, 379-387. 